\title{
TYMPANOMETRIC CHANGES IN GASTRO ESOPHAGEAL REFLUX DISEASE PATIENTS
}

By

\author{
Ahmed Mostafa Abd El-Moniem Ali, Ahmed Mohamed Ahmed and \\ Mostafa Shams El-Din Abd El-Haliem
}

Department of Otorhinolaryngology Faculty of Medicine, Al-Azhar University, Egypt

E-mail: ahmed_mostafa19883@yahoo.com

\begin{abstract}
Background: Gastroesophageal reflux (GERD), in particular extra-esophageal reflux, has been associated with a variety of upper aerodigestive tract symptoms or diseases, such as sinusitis and otitis. Many studies showed the role of reflux in chronic otitis media in children.

Objective: To survey tympanometric changes in gastro esophageal reflux disease patients by tympanometry.

Patients and methods: Prospective cross-sectional study included 40 cases with GERD and 20 persons without GERD as a control group. All cases were subjected to history taking and ENT examination. Moreover, tympanometry was performed for all cases.

Results: The mean age of the included cases were 32.7 years. Patients were 25 females $(62.5 \%)$ and 15 males $(37.5 \%)$. The mean value of GERD score was 11.18 (range, $10-12$ ). The four tympanogram types did not differ in age and gender, all the cases with type $\mathrm{B}$ and $\mathrm{C}$ tympanometry in the right ear was with GERD score of 11 and 12.
\end{abstract}

Conclusion: GERD may induce type $\mathrm{B}$ and $\mathrm{C}$ tympanometric changes, suggestive of eustachian tube dysfunction.

Keywords: Tympanomety; Gastroesophageal reflux disease.

\section{INTRODUCTION}

Gastroesophageal reflux disease (GERD) is a disorder in which gastric contents reflux recurrently into esophagus, causing troublesome symptoms (Gyawali and Fass., 2018). Typical symptoms of reflux are heartburn (retrosternal burning sensation) and acid regurgitation. Some patients more easily understand acid regurgitation, meaning the experience of sour or acidic fluid in the mouth (Chuang et al., 2017).

GERD symptoms among patients are more protean, and atypical symptoms may occur in the absence of heartburn and acid regurgitation (Sandhu and Fass. 2018).

Extra esophageal reflux has been implicated as an etiological factor in otitis media with effusion, especially in infants. Both conditions are very common in the first year of life. More recent studies have shown the presence of pepsin/ pepsinogen in the middle ear cleft with a much higher prevalence in children with purulent otitis media than in the control group. However, a clinical history of GERD, allergy, or asthma did not correlate with findings of extra esophageal reflux in the middle ear (Zerbib and Dulery. 2017). Extraesophageal reflux (EER) is supposed to be 
as a possible associated factor in the pathogenesis of otitis media and Eustachian tube dysfunction (Kavitt et al., 2017).

Tympanometry is one of the most frequently performed and important components of the basic audio logic evaluation. Tympanometry measures how the middle-ear system responds to sound energy, and how it reacts dynamically to changes in atmospheric pressure (Katz et al., 2015).

Tympanometry measures how the admittance changes as a function of applied air pressure and how this function is affected by different conditions of the middle ear. A special graph, a tympanogram, used for tympanometry (Libwea et al., 2018).

Tympanograms are categorized according to the shape of the plot. A normal tympanogram (left) is labeled Type A. There is a normal pressure in the middle ear with normal mobility of the eardrum and ossicles. Type B tympanogram may reveal fluid in the middle ear, perforation of the tympanic membrane or patent pressure equalization tube, or a tumor in the middle ear. Type $\mathrm{C}$ tympanograms are consistent with negative pressure in the middle ear space resulting from compromised eustachian tube function and a retracted tympanic membrane (Kataoka et al., 2019).

The present study aimed to survey tympanometric changes in patients with gastro esophageal reflux disease by tympanometry.

\section{PATIENTS AND METHODS}

This were a cross sectional observational study designed to survey tympanometric changes in gastro esophageal reflux disease patients measured by tympanometry. This study included 40 patients complaining from gastro esophageal reflux disease, and 20 persons without gastro-esophageal reflux disease as a control group, in outpatient Otorhinolaryngology Clinic at Al-Azhar University hospitals, Cairo, Egypt.

Inclusion criteria: All patients (except those in control group) who had score over 8 points at gastro esophageal reflux Disease Questionnaire (Dent et al., 2010).

Exclusion criteria: Patients with score less than 8 points at gastro esophageal reflux questionnaire, patients with otogenic diseases not caused by gastro esophageal reflux Disease, and patients with nasal diseases (congenital, traumatic, inflammatory, neoplastic).

A written informed consent was obtained from every participant before inclusion in the study after explaining the value of the study, plus the conducted procedure.

The whole study design was approved by the ethics committee of the Faculty of Medicine, Al-Azhar University.

All cases in the study were subjected to complete history taking, general medical history and associated comorbidities, and clinical examination. All patients were subjected to tympanometry, anterior rhinoscopy and otoscopy.

\section{Statistical analysis:}

The collected data were coded, processed and analyzed using the SPSS 
(Statistical Package for Social Sciences) version 22 for Windows ${ }^{\circledR}$ (SPSS Inc, Chicago, IL, USA). Data of the categorical variables were presented as number (frequency) and comparison between two groups containing qualitative data was compared using Chi-Square test (X2). Quantitative data was checked for normal distribution by using KolmogorovSmirnov test. Parametric data was presented as mean \pm SD. Student t-test was used to compare two groups with parametric quantitative data (expressed as t). Non parametric data was presented as median (min - max). Mann-Whitney test (expressed as Z) was used for comparison between groups. $\mathrm{P}$ value $\leq 0.05$ was considered significant; Kruskal-Wallis test was used for comparing ordinal or nonNormal variables between groups.

\section{RESULTS}

The mean age of the included cases in cases group was 32.7 years (range, 15 65). We included 25 females $(62.5 \%)$ and 15 males $(37.5 \%)$. The mean value of GERD score was 11.18 (range, $10-12$ ), the mean age of the included cases in control group was 33.45 years (range, 16 - 63). We included 9 (45\%) females, and 11(55\%) males (Table 1).

Table (1): analysis of demographic data of the cases in the two study groups

\begin{tabular}{|c|c|c|c|c|c|c|}
\hline \multicolumn{2}{|c|}{ Parameters } & \multicolumn{2}{|c|}{$\begin{array}{c}\text { Cases group } \\
(\mathrm{N}=40)\end{array}$} & \multicolumn{2}{|c|}{$\begin{array}{l}\text { Control group } \\
\qquad(\mathbf{N}=\mathbf{2 0})\end{array}$} & $\begin{array}{c}\text { Test of } \\
\text { significance }\end{array}$ \\
\hline \multicolumn{7}{|c|}{ Age (years) } \\
\hline \multicolumn{2}{|c|}{ Mean \pm SD } & \multicolumn{2}{|c|}{$32.7 \pm 14.35$} & \multicolumn{2}{|c|}{$33.45 \pm 14.27$} & \multirow{2}{*}{$\mathrm{p}=0.246$} \\
\hline \multicolumn{2}{|c|}{ Median (Range) } & \multicolumn{2}{|c|}{$29(15-65)$} & \multicolumn{2}{|c|}{$31(16-63)$} & \\
\hline \multirow{2}{*}{ Sex } & Males & 15 & $37.5 \%$ & 11 & $55 \%$ & \multirow{2}{*}{$\mathrm{P}=0.197$} \\
\hline & Females & 25 & $62.5 \%$ & 9 & $45 \%$ & \\
\hline
\end{tabular}

P: probability.

On performing tympanometry for the control group right ears, type A was the commonest one encountered (19 cases $95 \%)$ and one male case of type C ( 1 case $-5 \%)$. As for left ears type A was the commonest one encountered (19 cases $95 \%)$ and one female case of type B (1 case $-5 \%$ ), on performing tympanometry for the cases group right ears, type A was the commonest one encountered (28 cases $-70 \%)$, followed by type B (7 cases -
17.5\%), then type $\mathrm{C}$ was described in 5 cases. Regarding the left ear, type A tympanogram was the commonest type ( 25 cases $-62.5 \%$ ), followed by type $\mathrm{C}$ ( 9 cases $-22.5 \%$ ). Type B was diagnosed in 6 cases respectively.

On comparing tympanogram types in the right ear, it was evident that gender did not constitute a significant difference between the 4 groups ( $p>0.05$ ). However, there was a significant 
difference regarding GERD score $(\mathrm{p}=\quad 0.018)$ and gender $(\mathrm{p}=0.015)$ (Table 2).

Table (2): Comparison of items according to groups of tympanogram curves in the right ear

\begin{tabular}{|c|c|c|c|c|}
\hline $\begin{array}{l}\text { Groups } \\
\text { Variables }\end{array}$ & $\begin{array}{l}\text { Type A } \\
(\mathrm{N}=28)\end{array}$ & $\begin{array}{c}\text { Type B } \\
\text { (N=7) }\end{array}$ & $\begin{array}{c}\text { Type C } \\
(\mathrm{N}=5)\end{array}$ & $\begin{array}{c}\text { Test of } \\
\text { significance }\end{array}$ \\
\hline \multicolumn{5}{|l|}{ Age } \\
\hline Mean \pm SD & $36 \pm 14.59$ & $30.14 \pm 10.73$ & $17.80 \pm 5.72$ & \multirow{3}{*}{$\mathrm{P}=0.015$} \\
\hline $\mathbf{P}_{1}$ & & 0.557 & 0.021 & \\
\hline $\mathbf{P}_{2}$ & & & 0.266 & \\
\hline \multicolumn{4}{|l|}{ Sex } & \multirow{3}{*}{$P=0.470$} \\
\hline Female & $19(67.9 \%)$ & $3(42.9 \%)$ & $3(60 \%)$ & \\
\hline Male & $9(32.1 \%)$ & $4(57.1 \%)$ & $2(40 \%)$ & \\
\hline \multicolumn{4}{|c|}{ GERD Score from (10_12) } & \multirow{4}{*}{$\mathrm{P}=0.018$} \\
\hline (10) & $8(28.6 \%)$ & $0(0 \%)$ & $0(0 \%)$ & \\
\hline (11) & $12(42.9 \%)$ & $2(28.6 \%)$ & $3(60 \%)$ & \\
\hline (12) & $8(28.6 \%)$ & $5(71.4 \%)$ & $2(40 \%)$ & \\
\hline
\end{tabular}

$\mathrm{P} 1=$ significance in relation to type A group

$\mathrm{P} 2=$ significance in relation to type $\mathrm{B}$ group

On comparing left ear tympanograms, it was evident that gender and age did not constitute a significant difference between the 4 groups $(p>0.05)$. However, there was a significant difference regarding GERD score $(\mathrm{p}=0.031)$ (Table 3).

Table (3): Comparison of items according to groups of tympanogram curves in the left ear

\begin{tabular}{|c|c|c|c|c|}
\hline $\begin{array}{l}\text { Groups } \\
\text { Variables }\end{array}$ & $\begin{array}{l}\text { Type A } \\
(\mathrm{N}=25)\end{array}$ & Type B $(\mathrm{N}=6)$ & $\begin{array}{l}\text { Type C } \\
\text { (N=9) }\end{array}$ & $\begin{array}{c}\text { Test of } \\
\text { significance }\end{array}$ \\
\hline \multicolumn{5}{|l|}{ Age } \\
\hline Mean \pm SD & $32.72 \pm 11.65$ & $31.83 \pm 18.80$ & $33.22 \pm 19.35$ & \multirow{3}{*}{$P=0.684$} \\
\hline $\mathbf{P}_{1}$ & & 0.990 & 0.996 & \\
\hline $\mathbf{P}_{2}$ & & & 0.983 & \\
\hline \multicolumn{4}{|l|}{ Sex } & \multirow{3}{*}{$P=0.506$} \\
\hline Female & $15(60 \%)$ & $3(50 \%)$ & $7(77.8 \%)$ & \\
\hline Male & $10(40 \%)$ & $3(50 \%)$ & $2(22.2 \%)$ & \\
\hline \multicolumn{4}{|l|}{ GERD Score } & \multirow{4}{*}{$P=0.031$} \\
\hline (10) & $6(24 \%)$ & $2(33.3 \%)$ & $0(0 \%)$ & \\
\hline (11) & $13(52 \%)$ & $0(0 \%)$ & $4(44.4 \%)$ & \\
\hline (12) & $6(24 \%)$ & $4(66.7 \%)$ & $5(55.6 \%)$ & \\
\hline
\end{tabular}

$\mathrm{P}=$ probability

$\mathrm{P} 1=$ significance in relation to type $\mathrm{A}$ group

$\mathrm{P} 2=$ significance in relation to type $\mathrm{B}$ group

\section{DISCUSSION}

This study revealed that there was an increase in incidence of type $\mathrm{B}$ and $\mathrm{C}$ tympanogram in GERD cases, which may indicate that Eustachian tube dysfunction is a common squeal of reflux. Although the four tympanogram types did not differ in age and gender, there was a significant difference regarding GERD score. 
Gastroesophageal reflux (GER), in particular extra-esophageal reflux, has been associated with a variety of upper aerodigestive tract symptoms or diseases such as sinusitis and otitis. Many studies showed the role of reflux in chronic otitis media in children (Górecka-Tuteja et al., 2016).

Gastroesophageal reflux is one of the etiological factors for otitis media, especially over the last 10 years. Children with persisting MEE also frequently have recurrent acute otitis media $(\mathrm{OM})$. MEE often interferes with hearing and can lead to speech and developmental delay. Furthermore, it is a chronic inflammatory condition, of which the causes are thought to be multifactorial. Bacterial infections, obstruction of the Eustachian tube, respiratory tract viruses, and formation of bacterial biofilms have all been suggested to play a role in the development of this condition (Brunworth et al., 2014).

Studies performed over the last 10 years support the relationship between otitis media with effusion (OME) and laryngopharyngeal reflux (LPR). The exact mechanism of LPR in the etiology of OME has not been clarified. There are four possible mechanisms of LPR in the etiology of OME: eustachian tube dysfunction due to LPR, stimulation of Muc5b gene expression in the middle ear epithelium by acidic content, proteolytic activity of refluxed pepsin in the middle ear, and stimulation of inflammation in the middle ear by refluxed $\mathrm{H}$. pylori in the stomach (Doğru et al., 2015).

In a study by Yüksel et al. (2013), like our study GERD were reported in 54.9\% of studied children with OME. However, concerning otitis and reflux in adults, the literature is limited to case reports. Reflux is probably linked to many cases of otitis media in adults and may lead to Eustachian tube dysfunction in such subjects. Reflux in adult subjects with otitis media is potentially different from the physiologic events observed in children, but the causal link between them remains unclear. Evaluation of more cases that could be diagnosed as reflux-induced otitis media is necessary for better understanding of the disease entity (Sone et al., 2013).

As there is a paucity of studies regarding the relationship between GERD and eustachian tube dysfunction, it is suggested that more studies should be conducted in the near future regarding that perspective.

\section{CONCLUSION}

GERD may induce type $\mathrm{B}$ and $\mathrm{C}$ tympanometric changes, suggestive of eustachian tube dysfunction.

\section{REFERENCES}

1. Brunworth JD, Mahboubi H, Garg R, Johnson B, Brandon B and Djalilian HR. (2014): Nasopharyngeal acid reflux and Eustachian tube dysfunction in adults. Annals of Otology, Rhinology \& Laryngology, 123(6): 415-419.

2. Chuang TW, Chen SC and Chen KT. (2017): Current status of gastroesophageal reflux disease: diagnosis and treatment. Acta gastro-enterologica Belgica, 80(3): 396-404.

3. Dent J, Vakil N, Jones R, Bytzer P, Schöning $\mathbf{U}$, Halling $\mathrm{K}$, Junghard $\mathrm{O}$ and Lind $\mathrm{T}$. (2010): Accuracy of the diagnosis of GORD by questionnaire, physicians and a trial of proton pump inhibitor treatment: the Diamond Study. Gut, 59(6): 714-721.

4. Doğru M, Kuran G, Haytoğlu S, Dengiz R and Arıkan OK. (2015): Role of laryngopharyngeal reflux in the pathogenesis 
of otitis media with effusion. J Int Adv Otol., 11(1): 66-71.

5. Górecka-Tuteja A, Jastrzębska I, Składzień J and Fyderek K. (2016): Laryngopharyngeal reflux in children with chronic otitis media with effusion. Journal of Neurogastroenterology and Motility, 22(3): 452-458.

6. Gyawali CP and Fass R. (2018): Management of gastroesophageal reflux disease. Gastroenterology, 154(2): 302-318.

7. Kataoka Y, Maeda Y, Fujisawa I, Sugaya A, Kariya S and Nishizaki K (2019): Clinical evaluation of $1,000-\mathrm{Hz}$ tympanometry for the diagnosis of exudative otitis media in Japanese infants. Journal of Otolaryngology of Japan, 112(7): 960-968.

8. Katz J, Chasin M, English K, Hood LJ, Tillery KL (2015): Handbook of clinical audiology. 7th ed. Pbl. Philadelphia: Wolters Kluwer Health. p.137.

9. Kavitt RT, Lal P, Yuksel ES, Ates F, Slaughter JC, Garrett CG, Higginbotham T and Vaezi MF. (2017): Esophageal mucosal impedance pattern is distinct in patients with extraesophageal reflux symptoms and pathologic acid reflux. Journal of Voice, 31(3): 347-351.

10. Libwea JN, Kobela M, Ndombo PK, Syrjänen RK, Huhtala $H$, Fointama $N$, Koulla-Shiro S, Nohynek H, Nuorti JP and Palmu AA. (2018): The prevalence of otitis media in 2-3 year old Cameroonian children estimated by tympanometry. International Journal of Pediatric Otorhinolaryngology, 115: 181-187.

11. Sandhu DS and Fass R (2018): Current trends in the management of gastroesophageal reflux disease. Gut and Liver, 12(1): 7-12.

12. Sone M, Kato T and Nakashima T (2013): Current concepts of otitis media in adults as a reflux-related disease. Otology \& Neurotology, 34(6): 1013-1017.

13. Yüksel F, Doğan M, Karataş D, Yüce S, Şentürk M and Külahli I. (2013): Clinical presentation of gastroesophageal reflux disease in children with chronic otitis media with effusion. The Journal of Craniofacial Surgery, 24(2): 380-383.

14.Zerbib F and Dulery C (2017): Facts and Fantasies on Extraesophageal Reflux. Journal of Clinical Gastroenterology, 51(9): 769-776. 


\section{قياس ضغط طبلة الأذن في مرضي الارتجاع المعدي المربئي}

أحمد مصطفي عبد المنعم علي, أحمد محمد أحمد, مصطفي شمس الاين عبد الحليم

قسم الأذن والأنف والحنجرة, كلية الطب، جامعة الأزهر

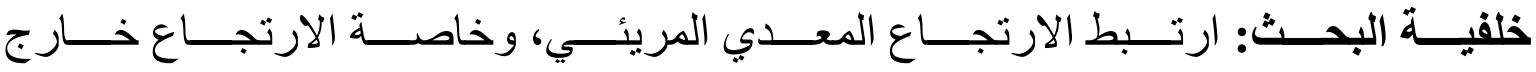

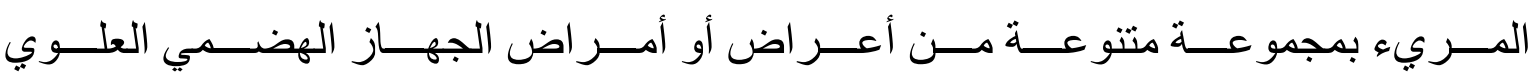

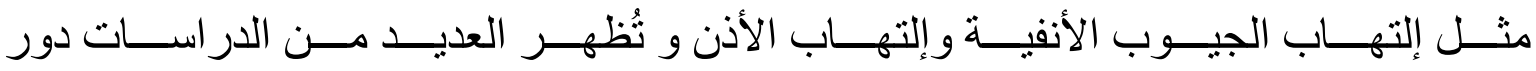
الارتجاع في إلتهاب الأذن الوسطى المزمن عند الأطفال.

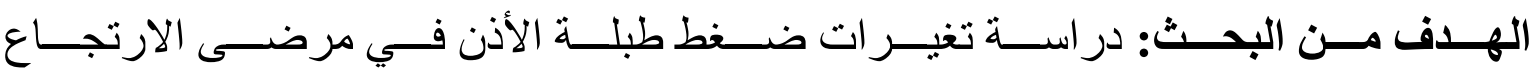
المعدي المريئي المقاس بقياسات ضغط طبلة الأذن.

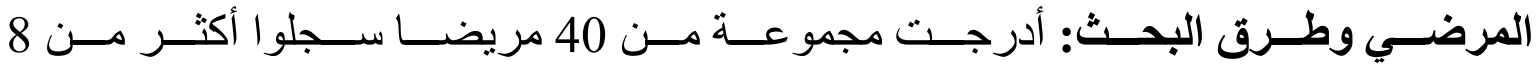

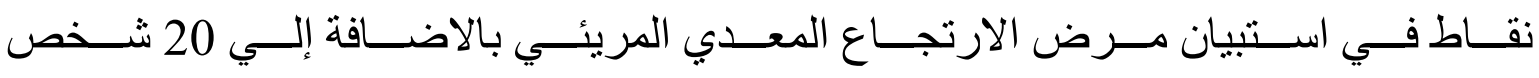

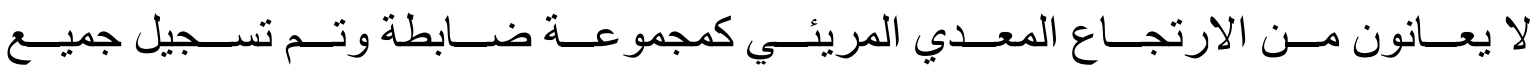

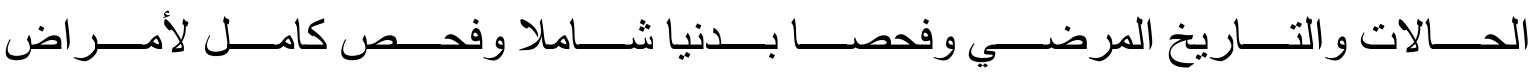

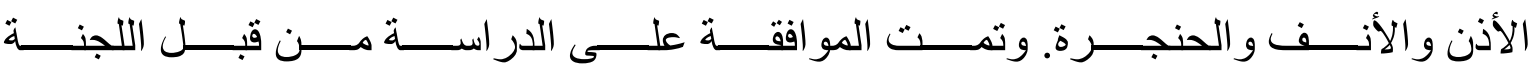

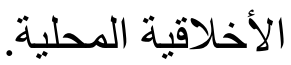

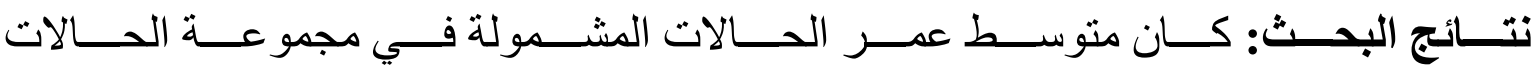

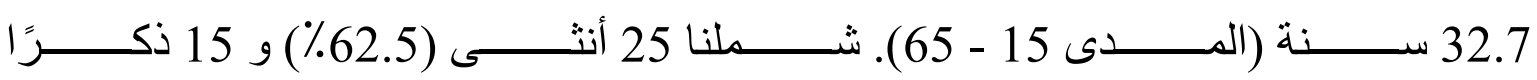

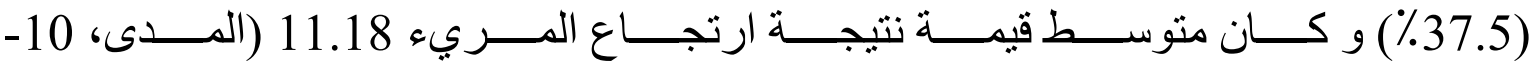

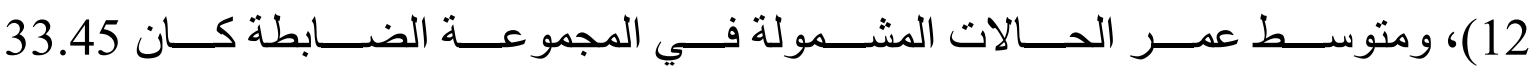

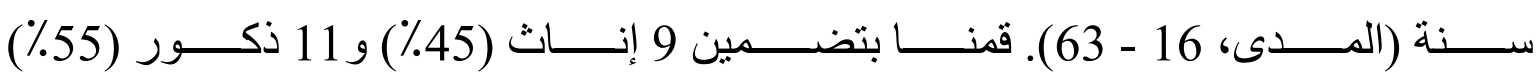

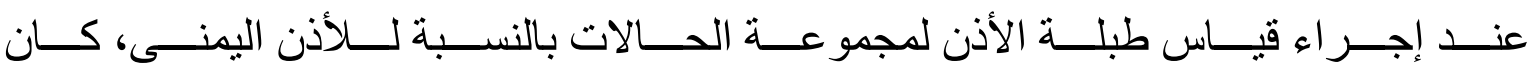

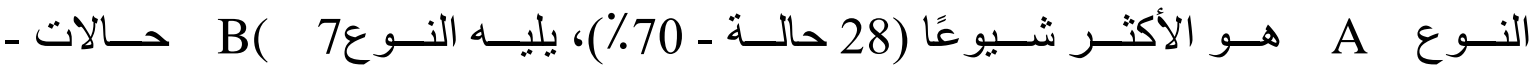

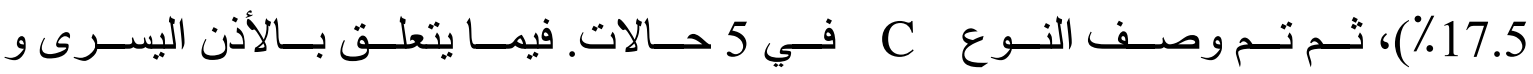

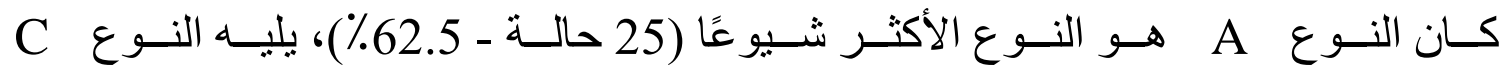




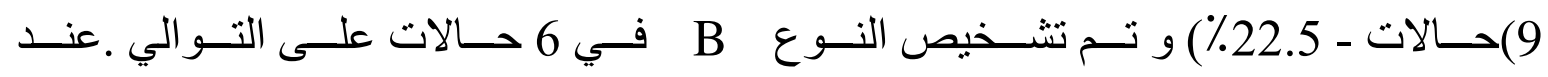

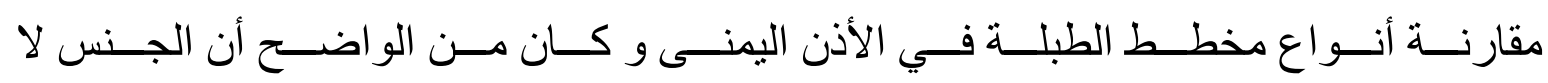

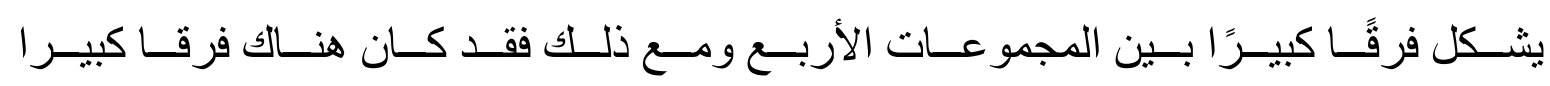

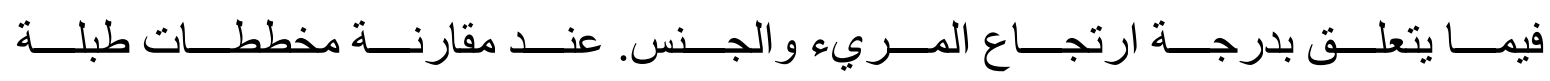

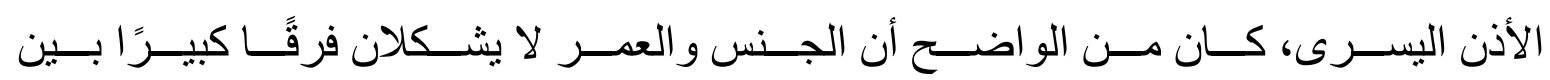

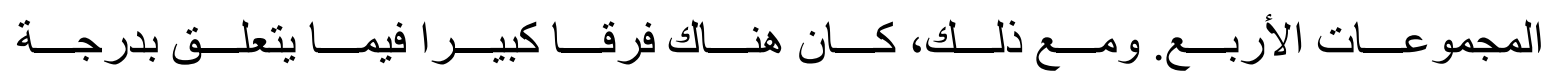
ارتجاع المريء.

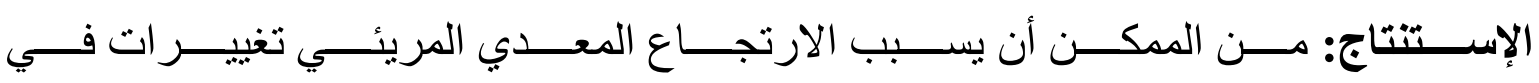
الطبلة من النو عين B و C ، مما يوحي بخلل وظيفي في قناة استاكيوس. 